\title{
Emerging Correlation Optics
}

Angelsky, Oleg V.; Gbur, Gregory J.; Polyanskii, Peter; Hanson, Steen G.; Volyar, Alexander; Zimnyakov, Dmitry A.; Mokhun, Igor

\section{Published in:}

Applied Optics

Link to article, DOI:

10.1364/AO.51.000CO1

Publication date:

2012

Document Version

Publisher's PDF, also known as Version of record

Link back to DTU Orbit

Citation (APA):

Angelsky, O. V., Gbur, G. J., Polyanskii, P., Hanson, S. G., Volyar, A., Zimnyakov, D. A., \& Mokhun, I. (2012). Emerging Correlation Optics. Applied Optics, 51(10), CO1-CO2. https://doi.org/10.1364/AO.51.000CO1

\section{General rights}

Copyright and moral rights for the publications made accessible in the public portal are retained by the authors and/or other copyright owners and it is a condition of accessing publications that users recognise and abide by the legal requirements associated with these rights.

- Users may download and print one copy of any publication from the public portal for the purpose of private study or research.

- You may not further distribute the material or use it for any profit-making activity or commercial gain

- You may freely distribute the URL identifying the publication in the public portal

If you believe that this document breaches copyright please contact us providing details, and we will remove access to the work immediately and investigate your claim 


\title{
Emerging Correlation Optics
}

\author{
Oleg V. Angelsky, ${ }^{1, \star}$ Gregory J. Gbur, ${ }^{2}$ Peter Polyanskii, ${ }^{1}$ Steen G. Hanson, ${ }^{3}$ \\ Alexander Volyar, ${ }^{4}$ Dmitry A. Zimnyakov, ${ }^{5}$ and Igor Mokhun ${ }^{1}$ \\ ${ }^{1}$ Chernivstsy National University, 2 Kotsyubinsky Street, Chernivtsy 58012, Ukraine \\ ${ }^{2} 7519$ Greylock Ridge Road, Mathews, North Carolina 28105, USA \\ ${ }^{3}$ DTU Fotonik 4000 Roskiilde, Denmark \\ ${ }^{4}$ Taurida National University, 4 Vernadsky Avenue, Simferopol 95007 Ukraine \\ ${ }^{5}$ Saratov State Technical University, Polytechnicheskaya Street 77 Saratov 410054, Russia \\ ${ }^{*}$ Corresponding author: angelsky@itf.cv.ua \\ Received 26 March 2012; \\ posted 26 March 2012 (Doc. ID 165525); published 30 March 2012
}

\begin{abstract}
This feature issue of Applied Optics contains a series of selected papers reflecting the state-of-the-art of correlation optics and showing synergetics between the theoretical background and experimental techniques. (C) 2012 Optical Society of America

OCIS codes: $\quad 110.0113,020.6580$.
\end{abstract}

As was realized in the middle of the 20th century (Emil Wolf), complete coherence and complete incoherence of optical radiation are far-reaching idealizations never realized in practice strictly, though they may be useful in many applications. Really, one always operates only with partially coherent, partially polarized waves, for which disturbances in one or different spatiotemporal points are in accordance, being in specific phase relations, in the statistical sense, i.e., involving time or ensemble averaging. This understanding led to the formation of a new direction of modern optics and photonics, often referred to as correlation optics, which has been brought up to date since the invention of lasers. Correlation optics is understood as the wave optics of partially coherent, inhomogeneously polarized light fields described (mainly but not only) in terms of correlation functions as the second-order statistical moments of various field parameters. For that, the following problem arises: correlation means just statistical accordance but not surely

$1559-128 \mathrm{X} / 12 / 100 \mathrm{CO} 1-02 \$ 15.00 / 0$

(C) 2012 Optical Society of America the cause-effect relation between two or more variables. The main purpose of correlation optics consists in establishing verisimilar interconnections between statistical parameters of a field scattered by an object and statistical characteristics of the object per se. A solution of this problem, as far as possible, would provide establishing the causeeffect relations between the object's structural and dynamic characteristics and the parameters of scattered fields. Knowledge of the mentioned interconnection leads to new metrological tools for optical diagnostics of light-scattering objects and media and to new experimental solutions of the inverse problems in optics, as well as interpretation of many important optical phenomena.

The past few years have seen increasing efforts of researchers in the field of correlation optics covering both classical "optics of observable quantities," as the statistical wave optics of partially coherent and partially or heterogeneously polarized light fields and more intimate and more intriguing singular optics of light beams supporting phase singularities of various complex parameters of a field. Ideas and data are now becoming available due to the establishment of correlation optics, allowing researchers to analyze 
and predict new phenomena and prospective applications of modern photonics and optoinformatics both in fundamentals and implementations of optical techniques. So, optical correlation techniques, including regular and polarization interferometry, interference/diffraction microscopy, specklometry, holographic correlometry, fractal optics, and measurement of optical chaos and optical singularities, constitute promising and quickly developed areas of optical IT. Such techniques (theoretical, computing, and experimental) serve to solve diverse applied problems ranging from industrial quality control to modern telecommunications and life sciences. Since 1993, ten biannual international conferences devoted to this large area of research and development have been held under the aegis of world-leading optical communities (SPIE, OSA, ICO, EPS, EOS). This feature issue of Applied Optics contains a series of selected papers reflecting the state-of-the-art of correlation optics and showing synergetics between theoretical background and experimental techniques such as the following:

- Informative content of statistical optical fields, including optical chaos, singular optics, polarization optics, and coherence.

- Optical correlation devices based on diffractive optical elements, including optical and digital holography, fractal optics, and optical sensors.

- Optical correlation diagnostics, interferometry, and microscopy of rough surfaces and random media.

- New applications of correlation optics in biology and medicine.

- Optical techniques, systems, and elements of telecommunications.

Guest Editors of the Feature Issue:

Oleg V. Angelsky, Greg Gbur, Peter V. Polyanskii, Steen G. Hanson, Alexander V. Volyar, Dmitry A. Zimnyakov, and Igor I. Mokhun. 